\title{
Papers
}

\section{Method for the measurement of antioxidant activity in human fluids}

\author{
D Koracevic, G Koracevic, V Djordjevic, S Andrejevic, V Cosic
}

\begin{abstract}
Aim-To develop a new, simple, and cheap method for estimating antioxidant activity in human fluids.

Methods-The assay measured the capacity of the biological fluids to inhibit the production of thiobarbituric acid reactive substances (TBARS) from sodium benzoate under the influence of the free oxygen radicals derived from Fenton's reaction. A solution of $1 \mathrm{mmol} / \mathrm{litre}$ uric acid was used as standard.

Results-The following mean (SD) antioxidative activities were found (as uric acid) in the various biological fluids: serum, $2.04(0.20) \mathrm{mmol} /$ litre; urine, 176.5 (25.6) $\mu \mathrm{mol} / \mathrm{litre}$; cerebrospinal fluid, 95.0 (26.9) $\mu \mathrm{mol} / \mathrm{litre}$; aqueous humour oculi, 61.25 (9.9) $\mu \mathrm{mol} / \mathrm{litre}$; saliva, 838.5 (48.2) $\mu \mathrm{mol} / \mathrm{litre}$; tears, 247.0 (17.0) $\mu \mathrm{mol} /$ litre; ascites fluid, 270.0 (63.3) $\mu \mathrm{mol} / \mathrm{litre}$; kidney cyst fluid, 387.1 (28.1) $\mu \mathrm{mol} / \mathrm{litre}$. Small samples of the biological material were needed for the analyses: $10 \mu 1$ of serum and 50-100 $\mu 1$ of other body fluids. In the sera of 48 healthy individuals there was a significant positive correlation between values obtained with the Randox method (as a reference method) and the new method proposed here (correlation coefficient, 0.8728; mean difference between methods, $<0.4 \%$ ).

Conclusions-This method is easy, rapid, reliable, and practical for the routine measurement of total antioxidant activity in serum and other human body fluids. Small samples of biological material are needed for the analyses and the results are comparable with the reference (Randox) method.

(F Clin Pathol 2001;54:356-361)
\end{abstract}

Keywords: antioxidant activity; free oxygen radicals; human fluids

Increased formation of reactive oxygen species and/or decreased antioxidant defence can be defined as oxidative stress, which is widely recognised as an important feature of many diseases. Cells and biological fluids have an array of protective antioxidant mechanisms, both for preventing the production of free radicals and for repairing oxidative damage. ${ }^{1-4}$
Several methods for serum antioxidative activity (AOA) determination have been developed. Most have been based on reduced production of malon dialdehyde: thiobarbituric acid reactive substances (TBARS); these methods have been used in rat liver homogenates, ${ }^{5}$ in phospholipid liposomes, ${ }^{6} 7$ in brain homogenates, ${ }^{8}$ with linoleic acid emulsion, ${ }^{9}$ and in preparations of red blood cell membranes. ${ }^{10} \mathrm{~A}$ method using auto-oxidation of a linethol/ unsaturated fatty acid mixture has also been suggested, ${ }^{11}$ as well as the oxygen electrode method, ${ }^{12}$ an enhanced chemiluminescence procedure, ${ }^{13}$ and the Randox method (which is available as commercial kits). However, the last three methods are not available in many laboratories and the spectrophotometric methods have poor reproducibility because of the instability of the substrates used for lipid peroxidation and TBARS formation.

Here, we present a very simple and quick method for total AOA measurement in serum and other biological fluids.

\section{Materials and methods}

CHEMICALS

Amino acids, human albumin, glutathione reduced $(\mathrm{GSH})$, and superoxide dismutase (SOD, from bovine erythrocytes, $3000 \mathrm{U} / \mathrm{mg}$ ) were supplied by Calbiochem (Lucerne, Switzerland), heparin solutions by ICN (Belgrade, Yugoslavia), hydrogen peroxide by Zorka (Sabac, Yugoslavia), and Trolox by Sigma-Aldrich (Steinheim, Germany). All other chemicals used were obtained from Merck Darmstadt (Germany) and were of analytical grade.

\section{PRINCIPLE}

A standardised solution of Fe-EDTA complex reacts with hydrogen peroxide by a Fentontype reaction, leading to the formation of hydroxyl radicals ('OH). These reactive oxygen species degrade benzoate, resulting in the release of TBARS. ${ }^{14-16}$ Antioxidants from the added sample of human fluid cause suppression of the production of TBARS. This reaction can be measured spectrophotometrically and the inhibition of colour development defined as the AOA.

SOLUTIONS

(1) Sodium phosphate buffer: $100 \mathrm{mmol} / \mathrm{litre}$, $\mathrm{pH} 7.4$ 
(2) sodium benzoate: $10 \mathrm{mmol} / \mathrm{litre}$

(3) $\mathrm{NaOH}: 50 \mathrm{mmol} /$ litre

(4) EDTA (acidum aethylendiamin tetraacetic): $2 \mathrm{mmol} /$ litre in phosphate buffer (solution 1)

(5) $\mathrm{Fe}(\mathrm{NH} 4)_{2} \mathrm{SO} 4: 2 \mathrm{mmol} /$ litre

(6) Fe-EDTA complex (prepared freshly by mixing equal volumes of solutions 4 and 5 , left to stand 60 minutes at room temperature)

(7) $\mathrm{H}_{2} \mathrm{O}_{2}: 10 \mathrm{mmol} /$ litre

(8) acetic acid: $20 \%$

(9) thiobarbituric acid (TBA): $0.8 \%$ (wt/vol) in $50 \mathrm{mmol} /$ litre $\mathrm{NaOH}$

(10) uric acid: $1 \mathrm{mmol} /$ litre in $5 \mathrm{mmol} /$ litre $\mathrm{NaOH}$.

Solutions 4-9 should be prepared immediately before use. The sodium phosphate buffer and sodium benzoate should be kept in a refrigerator $\left(0-4^{\circ} \mathrm{C}\right)$ and the uric acid solution in a deep freeze $\left(-20\right.$ to $\left.-30^{\circ} \mathrm{C}\right)$.

ANALYTICAL PROCEDURE

Each sample $\left(A_{1}\right)$ should have its own control $\left(\mathrm{A}_{0}\right.$, sample blank) in which the Fe-EDTA mixture and $\mathrm{H}_{2} \mathrm{O}_{2}$ should be added after $20 \%$ acetic acid. For each series of analysis a negative control $\left(\mathrm{K}_{1}\right.$ and $\left.\mathrm{K}_{0}\right)$ should be prepared (at least in triplicate), containing the same reagents as $A_{1}$ or $A_{0}$, except that serum (or other human fluid) is replaced with phosphate buffer. Standards containing $1 \mathrm{mmol} /$ litre uric acid $\left(\mathrm{UA}_{1}\right.$ and $\left.\mathrm{UA}_{0}\right)$ are used for calibration.

Pipette into tubes (in millilitres):

$\begin{array}{lllllll} & \mathrm{A}_{1} & \mathrm{~A}_{0} & \mathrm{~K}_{1} & \mathrm{~K}_{0} & \mathrm{UA}_{1} & \mathrm{UA}_{0} \\ \text { Serum } & 0.01 & 0.01 & - & - & - & - \\ \text { Uric acid } & - & - & - & - & 0.01 & 0.01 \\ \text { Buffer } & 0.49 & 0.49 & 0.50 & 0.50 & 0.49 & 0.49 \\ \text { Na-benzoate } & 0.50 & 0.50 & 0.50 & 0.50 & 0.50 & 0.50 \\ \text { Acetic acid } & - & 1.00 & - & 1.00 & - & 1.00 \\ \text { Fe-EDTA } & 0.20 & 0.20 & 0.20 & 0.20 & 0.20 & 0.20 \\ \mathrm{H}_{2} \mathrm{O}_{2} & 0.20 & 0.20 & 0.20 & 0.20 & 0.20 & 0.20 \\ \text { Incubate for } 60 \text { minutes at } 37^{\circ} \mathrm{C} \text {, then add: } \\ \text { Acetic acid } & 1.00 & - & 1.00 & - & 1.00 & - \\ \text { TBA } & 1.00 & 1.00 & 1.00 & 1.00 & 1.00 & 1.00\end{array}$

Incubate for 10 minutes at $100^{\circ} \mathrm{C}$ (in a boiling water bath) then cool in an ice bath. Measure absorbance at $532 \mathrm{~nm}$ against deionised water.

\section{CALCULATION}

Antioxidant activity should be calculated as follows:

AOA $\quad(\mathrm{mmol} /$ litre $)=\left(\mathrm{C}_{\mathrm{UA}}\right) \quad(\mathrm{K}-\mathrm{A}) /$

$(\mathrm{K}-\mathrm{UA})$

where

$\mathrm{K}=$ absorbance of control $\left(\mathrm{K}_{1}-\mathrm{K}_{0}\right)$

$A=$ absorbance of sample $\left(A_{1}-A_{0}\right)$

$\mathrm{UA}=$ absorbance of uric acid solution $\left(\mathrm{UA}_{1}-\mathrm{UA}_{0}\right)$

$\mathrm{C}_{\mathrm{UA}}=$ concentration of uric acid (in $\mathrm{mmol} /$ litre).

STATISTICAL ANALYSIS

Student's $t$ test, correlation, and regression analyses were used with commercial PC programs Nanostat and Excel. We also used the method of Bland and Altman. ${ }^{17}$

\section{Results}

STORAGE

For the determination of stability in relation to time and storage temperature, the serum was split into separate portions immediately after blood centrifugation; the samples were kept in capped tubes at $0-4^{\circ} \mathrm{C}$ for 40 hours, at room temperature $\left(21-22^{\circ} \mathrm{C}\right)$ for 40 hours, or at $-20^{\circ} \mathrm{C}$ for 40 hours or one month until assayed. The starting AOA was determined immediately after serum collection. All assays were carried out in triplicate. There were no differences between AOA in samples of serum kept under all these condition.

CALIBRATION

Uric acid and a water soluble analogue of vitamin E, Trolox (6-hydroxy-2,5,7,8tetramethoxylchroman-2-carbon seaure), were used for calibration. Standard uric acid solutions were made in $5 \mathrm{mM} \mathrm{NaOH}$, and Trolox solutions were made in phosphate buffer (100 mM, pH 7.4).

Uric acid (500-2500 $\mu \mathrm{mol} /$ litre; working solutions) as a standard caused linear inhibition of TBARS production. Increasing the uric acid concentration (by adding 50-100 $\mu$ of the standard $3 \mathrm{mM}$ solution of uric acid) did not cause $100 \%$ inhibition of the free radical reaction. Maximal inhibition of TBARS production by uric acid was $80 \%$.

Trolox (a water soluble analogue of vitamin E) as standard caused linear inhibition at concentrations of 100-1200 $\mu \mathrm{mol} /$ litre (working Trolox solution). When the concentration of Trolex was increased the maximal inhibition of TBARS production was $75 \%$.

However, increasing the serum volume in the incubation medium could cause $100 \%$ inhibition of the reaction (keeping the other conditions constant). In most cases, $50 \mu \mathrm{l}$ (and in all cases, $100 \mu \mathrm{l}$ ) of serum was sufficient to produce complete inhibition of TBARS production.

Therefore, we concluded that uric acid or Trolox could be used for calibration. We chose to use uric acid because it is a natural constituent of human fluids. Thus, we presented all our results either as $\mathrm{mmol}$ or $\mu \mathrm{mol}$ of uric acid/litre of biological fluid.

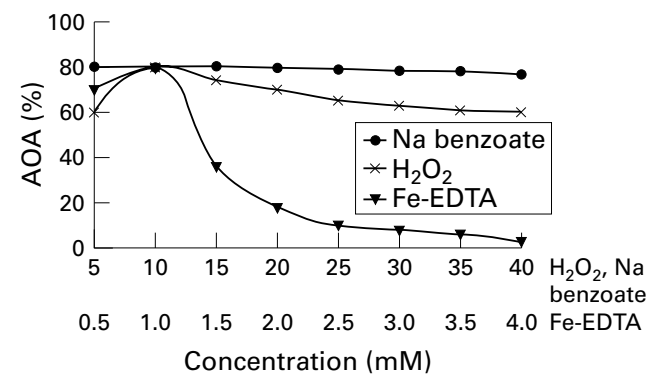

Figure 1 Influence of the concentration of reagents on antioxidant activity ( $A O A)$. Na benzoate was used at 5-40 mM (while $\mathrm{Fe}-E D T A$ was kept at $1 \mathrm{mM}$ and $\mathrm{H}_{2} \mathrm{O}_{2}$ at $10 \mathrm{mM}$ ). $\mathrm{H}_{2} \mathrm{O}_{2}$ was used at 5-40 $\mathrm{mM}$ (while $\mathrm{Fe}-\mathrm{EDTA}$ was kept at $1 \mathrm{mM}$ and $\mathrm{Na}$ benzoate at $10 \mathrm{mM}$ ).

$\mathrm{Fe}-E D T A$ was used at 0.5-4 $\mathrm{mM}$ (while $\mathrm{H}_{2} \mathrm{O}_{2}$ was kept at $10 \mathrm{mM}$ and $\mathrm{Na}$ benzoate at $10 \mathrm{mM}$ ). 


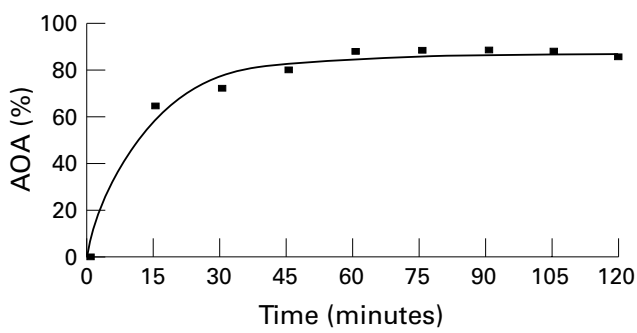

Figure 2 Influence of incubation time on benzoate degradation. AOA, antioxidant activity.

Table 1 Influence of thiobarbituric acid (TBA) reaction time on antioxidant activity $(A O A)$

\begin{tabular}{lllll}
\hline $\begin{array}{l}\text { Time } \\
\text { (min) }\end{array}$ & $K_{1}-K_{0}$ & $A_{1}-A$ & $U A_{1}-U A_{0}$ & $\begin{array}{l}A O A \\
(\mathrm{mmol} / \mathrm{l})\end{array}$ \\
\hline 10 & 0.233 & 0.103 & 0.152 & 1.6 \\
20 & 0.288 & 0.112 & 0.178 & 1.6 \\
30 & 0.344 & 0.123 & 0.206 & 1.6 \\
40 & 0.396 & 0.132 & 0.231 & 1.6 \\
50 & 0.445 & 0.139 & 0.254 & 1.6 \\
60 & 0.492 & 0.146 & 0.276 & 1.6 \\
\hline
\end{tabular}

$\mathrm{K}_{1}-\mathrm{K}_{0}$, absorbance of control; $\mathrm{A}_{1}-\mathrm{A}$, absorbance of sample; $\mathrm{UA}_{1}-\mathrm{UA}_{0}$, absorbance of $1 \mathrm{mM}$ uric acid.

INFLUENCE OF THE CONCENTRATION OF THE REAGENTS

The effect of the concentration of different reagents upon AOA was analysed, namely: Fe-EDTA (0.5-4.0 mmol/litre), $\mathrm{H}_{2} \mathrm{O}_{2}$, and $\mathrm{Na}$ benzoate (5.0-10.0 mmol/litre). In these experiments, the concentration of one reagent was changed while the concentrations of the other two reagents were kept constant. All measurements were performed in triplicate. Figure 1 gives the results. Changes in the concentration of the Fe-EDTA complex had the strongest impact on AOA determination. The most appropriate concentrations of Fe-EDTA were in the range $0.75-1.25 \mathrm{mmol} /$ litre (working solution).

INFLUENCE OF INCUBATION TIME

Reaction mixtures of analyses and blanks (containing human serum), controls (without serum), as well as uric acid solutions were prepared and then incubated at $37^{\circ} \mathrm{C}$. Portions of the tube contents were removed for the TBA reaction according to a determined time sequence. An incubation time of 60 minutes gave the maximal AOA value (fig 2). Therefore, an incubation time of one hour appeared to be optimal.

INFLUENCE OF TBA REACTION TIME (IN BOILING WATER BATH)

Table 1 presents the results of this analysis. All assays were done in triplicate with the same serum samples. Increasing the reaction time from 10 to 60 minutes resulted in augmentation of absorbance for both analysis and standard samples, without a change in AOA.

REPRODUCIBILITY

Within run precision gave coefficients of variation (CV) of $4.3 \%$ and $5.4 \%$ based on 12 measurements both of normal AOA and low AOA, respectively (prepared by dilution of sera with water). Day to day precision for 18 assays (every set of assays contained 10 samples) of the pooled serum gave a $\mathrm{CV}$ of $4.8 \%$.

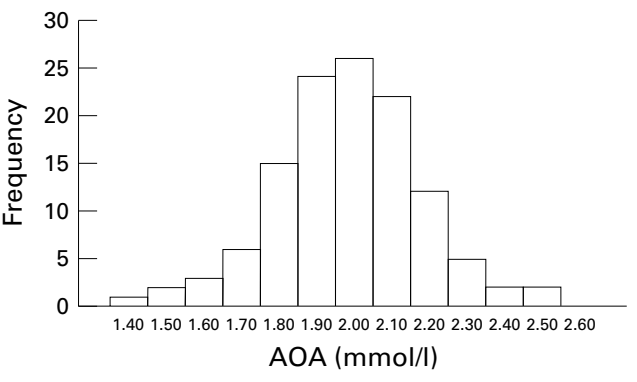

Figure 3 Frequency distribution of serum antioxidant activity (AOA) in healthy subjects.

REFERENCE VALUES FOR SERUM AOA

The biological variance of serum AOA was studied in 120 subjects (80 men and 40 women) who came for health screening and proved to be healthy. We found a Gaussian type frequency of distribution of AOA (fig 3). Therefore, the reference interval was calculated as mean \pm 2 SD: from 1.63-2.44, with 114 (95\%) of all values within this range. Statistical parameters are: range, 1.42-2.59; mean, 2.04; SD, 0.20. No significant difference was found between men and women $(p>0.05)$.

COMPARISON OF PROPOSED AND REFERENCE METHOD

We compared our proposed method with an established method (Randox) in sera from 48 individuals. Mean (SD) values were 1.08 (0.28) $\mathrm{mmol} /$ litre with the Randox test and 1.94 (0.39) mmol/litre with our method. There was a significant correlation between the two methods (correlation coefficient, 0.8728; $\mathrm{p}<0.0001)$.

Regression analysis: $\mathrm{F}=147.09 ; \mathrm{t}=12.128$; slope, 1.23841; y intercept, 0.60019 .

For comparison between the two methods we also used the "more adequate procedure". ${ }^{17}$ Most of the differences against the mean difference were in the range mean \pm 2 SD (fig 4).

In addition, we found the "correction factor" 1.8 from the first 24 healthy persons by dividing values obtained from our proposed method by values obtained using the reference method. Then we tested this correction factor on the other 24 individuals (by dividing AOA values measured with our method by 1.8) and compared them with values obtained by the reference method. After this correction, all the differences were within the range of the mean value $\pm 2 \mathrm{SD}$ (fig 5). In addition, absolute values of differences became minimal. Namely, the average "relative mean difference" (the mean difference by the two methods divided by the mean of values obtained with the reference method) was 0.00384 . This suggests that the mean difference for individual values obtained by the reference and proposed methods is $<0.4 \%$. Thus, our proposed method (after correcting values simply by dividing them by 1.8 ) can be used interchangeably with the reference method.

EFFECTS OF DIALYSIS AND HIGH TEMPERATURE

Sera from six healthy persons were used for this investigation. Each serum sample was 


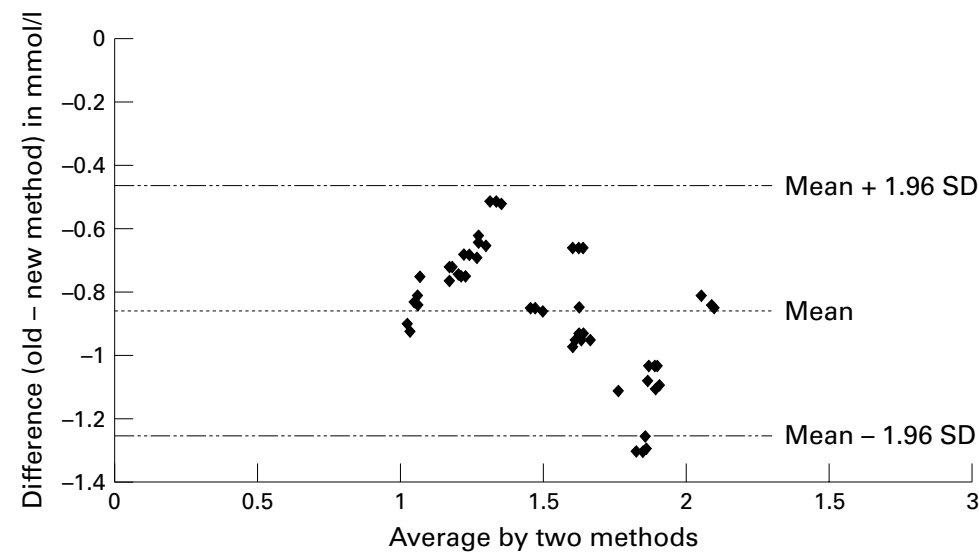

Figure 4 Mean difference between the two methods.

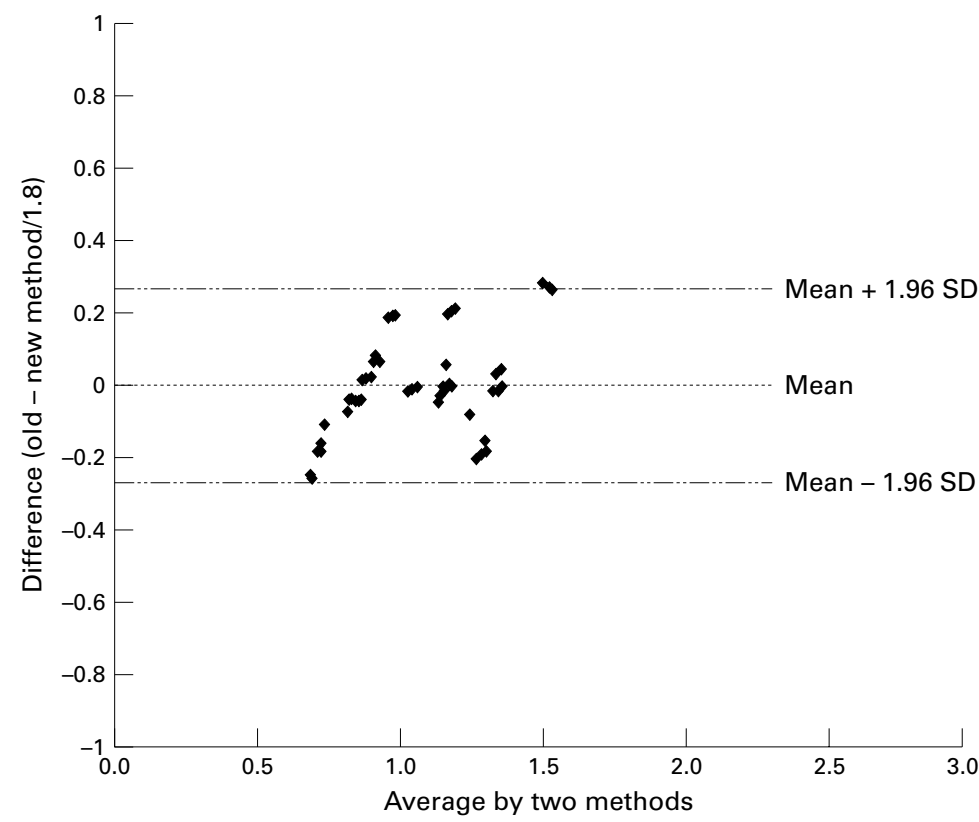

Figure 5 Mean difference between the Randox method and our proposed method after correction.
Table 2 The concentrations (mmol/litre) of some serum constituents needed for $50 \%$ antioxidative activity

\begin{tabular}{ll}
\hline Substances & $E C_{50}(\mathrm{mmol} / \mathrm{l})$ \\
\hline Uric acid & 0.005 \\
Albumin & 0.1 \\
Sodium pyruvate & 0.2 \\
Glutathione reduced & 1.0 \\
Arginine & 2.5 \\
Tryptophan & 2.5 \\
Cysteine & 5.0 \\
\hline
\end{tabular}

naturally occurring antioxidants that we studied had no pronounced effect on AOA. Superoxide dismutase $(45 \mathrm{U} / \mathrm{ml}$ of incubation medium) decreases TBARS formation by $53 \%$. Vitamin $\mathrm{C}$ and bilirubin interfere with the TBA reaction itself and their AOA cannot be estimated using our proposed new method.

Because of their turbidity, serum lipids led to an increased absorbance both of samples and blanks $(0.045$ at $10.0 \mathrm{~g} /$ litre lipid concentration). Because of their colour, icteric sera and haemoglobin caused a weak increase of absorbance both in samples and blanks and haemolysis caused the release of constituents from red blood cells into serum. Catalase and haemoglobin destroy $\mathrm{H}_{2} \mathrm{O}_{2}$ in the incubation medium, resulting in increased AOA values.

INFLUENCE OF ANTICOAGULANTS

Blood specimens were obtained from five healthy persons for heparinised plasma, citrate plasma, and serum. Analyses were done in triplicate. There was no difference in AOA values between serum and plasma. Citrate is a known iron chelating agent, but in our method the plasma sample is diluted 141 times. Therefore, the concentration of anticoagulants is very low and they do not affect the iron concentration in the incubation medium. Thus, the anticoagulants did not act either as (pro)oxidants or antioxidants. We conclude that for our proposed method either serum or blood plasma can be used.

divided into three portions. The first one was not treated, the second underwent dialysis (18 hours against $\mathrm{H}_{2} \mathrm{O}$ ), and the third was heated for five minutes in a boiling water bath (and then cooled). In each sample, the AOA was determined (in triplicate). In untreated samples, AOA values were from $1.85-2.40 \mathrm{mmol} /$ litre. Dialysis reduced the AOA by $58.27 \%$ and high temperature by $39.86 \%$ (from basal values).

AOA OF SOME SERUM CONSTITUENTS

Table 2 gives the antioxidant activities of the major natural serum antioxidants. Various concentrations of these substances were added to the incubation medium (without serum) to investigate their dose dependent effect upon TBARS release. The final concentrations (in the incubation medium) of antioxidants capable of $50 \%$ reduction of TBARS production were defined as $50 \%$ effective concentrations $\left(\mathrm{EC}_{50}\right)$. The data from table 2 suggest that physiological concentrations of uric acid, albumin, and pyruvate contribute to AOA. Other
AOA IN OTHER HUMAN FLUIDS

Our proposed method can be used for AOA determination in other biological fluids. In this preliminary investigation the following fluids were used: saliva, urine, tears, aqueous humour oculi, cerebrospinal fluid, kidney cyst fluid, and ascites fluid. In each fluid AOA was present (table 3), but with a lower intensity than in serum (mean, $2040 \mu \mathrm{mol} /$ litre; SD, 20).

Thus, when analysing these other biological fluids using our method, 50-100 $\mu$ l should be used, except for saliva, where $10 \mu$ is sufficient. We obtained the following samples: $10 \mu \mathrm{l}$ of serum and of saliva, $50 \mu \mathrm{l}$ of ascites fluid and of

Table 3 Antioxidant activity ( $A O A$ ) in a variety of human fluids

\begin{tabular}{lcc}
\hline Biological fluid & Number of subjects & AOA ( $\mu \mathrm{mol} / \mathrm{l})$ \\
\hline Saliva & 20 & $838.5(48.2)$ \\
Urine & 20 & $176.5(25.6)$ \\
Cerebrospinal fluid & 6 & $100.8(24.2)$ \\
Humour aqueous oculi & 8 & $61.3(9.9)$ \\
Ascites fluid & 9 & $270.0(63.3)$ \\
Tears & 10 & $247.0(17.0)$ \\
Kidney cyst fluid & 7 & $387.1(28.1)$ \\
\hline
\end{tabular}

Values are mean (SD). 


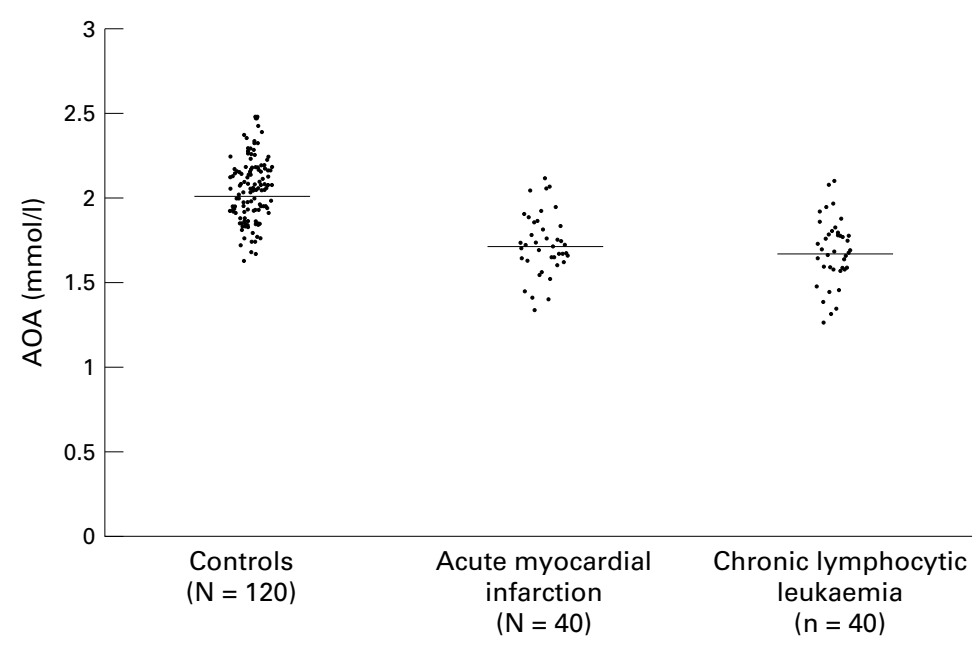

Figure 6 Antioxidant activity (AOA) in human serum.

kidney cyst fluid, and $100 \mu \mathrm{l}$ of urine, tears, cerebrospinal fluid, and aqueous humour oculi. Saliva was collected from 20 medical students, who were free of mouth and tooth disease. Urine was obtained from individuals without kidney and urinary tract disease. Other biological fluids were taken from patients for diagnostic purposes. Cerebrospinal fluid was obtained from patients with meningitis (nine patients: mean AOA, $53.3 \mu \mathrm{mol} / \mathrm{litre}$; $\mathrm{SD}, 18.7$ ) and from six patients (mean AOA, $100.8 \mu \mathrm{mol} /$ litre; SD, 24.2) who were later found to be free of central nervous system disease. There was a significant difference between AOA in the two groups $(t=4.296$; $\mathrm{p}=0.0009$ ). Aqueous humour oculi was obtained from patients who were operated on because of senile cataract. The diagnostic value of AOA in various human fluids determined with our proposed method is currently under investigation.

AOA IN SERA OF HEALTHY VERSUS SICK INDIVIDUALS

AOA was determined in the serum of 120 clinically healthy persons and 80 patients: 40 with acute myocardial infarction (AMI) and 40 with chronic lymphocytic leukaemia (CLL). Blood samples from patients with AMI were taken at the time of arrival at the department for cardiovascular diseases. Figure 6 shows the results. In patients with $\mathrm{AMI}$, the mean (SD) AOA was $1.73(0.18) \mathrm{mmol} / \mathrm{litre}$ and in patients with CLL these values were 1.68 (0.19) $\mathrm{mmol} /$ litre. In comparison with 120 healthy subjects (mean AOA, $2.04 \mathrm{mmol} / \mathrm{litre}$; $\mathrm{SD}, 0.2$ ), both patients with AMI and those with CLL had significantly lower AOA $(\mathrm{t}>8.3 ; \mathrm{p}<0.0001)$.

\section{Discussion}

The total antioxidative serum capacity is not a simple sum of the activities of the various antioxidative substances. It is a dynamic equilibrium that is influenced by the interactions between each serum antioxidative constituent. It is thought that the cooperation of antioxidants in human serum provides greater protection against attacks by free radicals than any antioxidant alone. ${ }^{18}$ Clinically relevant antioxidants are classified into two groups: preventive and chain breaking antioxidants. ${ }^{18} 19$ Preventive antioxidants prevent the initiation of radical chain reactions by reducing hydroperoxides to molecular species without the formation of free radicals, or by sequestering transition metals (iron, copper), thereby preventing them from participating in reactive radical production. Chain breaking antioxidants can trap free radicals directly, thereby interrupting chain propagating reactions. The known preventive antioxidants of biological systems are: catalase, glutathione peroxidase, and metal binding proteins (transferrin, ceruloplasmin, and albumin); chain breaking antioxidants are: SOD, uric acid, protein sulphhydryls, ascorbate, $\alpha$-tocopherol, GSH, and bilirubin. ${ }^{18} 19$ Uric acid exerts antioxidant activity (as a chain breaking agent) by scavenging oxygen radicals once they are produced, ${ }^{20}$ and by forming a stable complex with iron ions ${ }^{21}$ (as a preventive antioxidant). Human blood plasma has a chain breaking antioxidant capacity that allows it to trap free radicals (approximately 0.70$1.00 \mathrm{mmol} /$ litre $).^{18}$

Valkonen and Kuusi ${ }^{22}$ used Trolox, as an international standard, to show that the mean value for serum TRAP (total peroxyl radical trapping potential) of healthy subjects was $1.155 \mathrm{mmol} /$ litre. With Randox tests (calibrated also with Trolox) values of 1.30$1.77 \mathrm{mmol} /$ litre have been reported. With our method, the mean (SD) AOA of sera from healthy persons was $2.04(0.2) \mathrm{mmol} /$ litre (as uric acid).

The differences between the reference method and our proposed method have no clinical importance because, as yet, AOA measurements are not used in clinical practice for diagnostics or the evaluation of treatment. The determination of total AOA and its components has been used for scientific purposes, to examine the medical importance of free oxygen radicals and antioxidative defence. ${ }^{19}{ }^{23}$ Furthermore, no single method is capable of detecting all components of AOA in serum, and there is no "gold standard" for total AOA measurement. ${ }^{13182324}$ This suggests that many comparable methods need to be used. The Randox method has been used frequently for total AOA determination in scientific research. Our proposed method gives comparable results.

There has been considerable debate concerning the antioxidative capacity of anticoagulants. ${ }^{25-28}$ Data presented in our paper show that AOA determination can be performed in both serum and heparinised/citrate plasma.

We found (table 2) that some normal serum constituents (uric acid, pyruvate, albumin) have high AOA. In contrast, arginine, cysteine, tryptophan, and GSH have only weak antioxidant activity. Their AOA can be detected (table 2) only in much higher concentrations than are found physiologically. We found uric acid to be a particularly strong serum antioxidant, which is in agreement with data from other authors. ${ }^{1824} 29$ The antioxidant activity of vitamin 
C cannot be measured using our method because ascorbate not only acts as a radical trapping agent, but can also undergo autooxidation, ${ }^{12}$ producing coloured substances that interfere with TBARS absorbance determination. According to the data from Halliwell, ${ }^{30}$ albumin inhibits copper but not iron dependent hydroxyl radical generation. In addition, albumin has other antiradical effects and it might be able to scavenge some hydroxyl radicals. ${ }^{30}$ Gutteridge et al found that albumin $(0.014 \mathrm{~g} /$ litre $)$ did not significantly change the production of TBARS from benzoate under the influence of Fe-EDTA and hydrogen peroxide. ${ }^{14}$ We found (table 2 ) that albumin at $6.8 \mathrm{~g} /$ litre (which is eight times lower than physiological plasma concentrations) exerts $50 \%$ AOA.

According to the data from Gutteridge et al, ${ }^{14}$ both hydroxyl radicals and superoxide anions are produced from the interaction of $\mathrm{Fe}-$ EDTA and $\mathrm{H}_{2} \mathrm{O}_{2}$. Our results confirm that SOD decreases TBARS production from benzoate. Physiological plasma SOD activity is minimal, but haemolysis might influence AOA measurements, owing to the release of SOD from red blood cells.

By means of dialysis and heat exposure we found that most AOA resides in the macromolecules-transition metals binding proteins, albumin, $\mathrm{SH}$ group containing proteins etc-which is in agreement with the results of other investigations. ${ }^{18}$ We found that Trolox (a chain breaking antioxidant) and uric acid (a preventive and chain breaking antioxidant) could not inhibit TBARS generation totally, but that serum could. This suggests that in serum AOA (as measured by our proposed method) other mechanisms of action are also involved.

\section{Conclusion}

Our method is easy, rapid, reliable, and practical for the routine measurement of total antioxidant activity in serum and other human body fluids. Small samples of biological material are needed for the analyses: $10 \mu \mathrm{l}$ of serum and saliva, and 50-100 $\mu$ lof other body fluids. Comparable results are obtained with our method and the reference (Randox) method.

1 Sies H. Oxidative stress: from basis research to clinical application. Am F Med 1991;91 (suppl 3C):31-8

2 Yu BP. Cellular defenses from damage from reactive oxygen species. Physiol Rev 1994;74:139-62.

3 Reiter RJ. Oxidative processes and antioxidative defense mechanisms. FASEB F 1995;9:526-33.
4 Halliwell B. Antioxidants in human health and disease. Annu Rev Nutr 1996:16:33-50.

5 Vidlakova M, Erazimova J, Horky J, et al. Relationship of serum antioxidative activity to tocopherol and serum inhibitor of lipid peroxidation. Clin Chim Acta 1972;36:616.

6 Gutteridge J, Hill C, Blake D. Copper stimulated phospholipid membrane peroxidation: antioxidant activity of serum and synovial fluid from patients with rheumatoid arthritis. Clin Chim Acta 1984;139:85-90.

7 Gutteridge J. Antioxidant properties of the proteins caeruloplasmin, albumin and transferrin. A study of their activity in serum and synovial fluid from patients with rheumatoid arthritis. Biochim Biophys Acta 1986;869:119-27.

8 Stocks J, Gutteridge J, Sharp R, et al. Assay using brain homogenate for measuring the antioxidant activity of homogenate for measuring the antioxidant act
biological fluid. Clin Sci Mol Med 1974;47:215-22.

9 Promislov $M$, Demcuk M. A modified procedure for estimation of total antioxidant activity of blood serum [abstract in English]. Vopr Med Khim 1990;36:90-2.

10 Spector E, Annanenko A, Politova L. Determination of the total antioxidizing activity of the blood plasma and liquor [abstract in English]. Lab Delo 1984;1:26-8.

11 Kulikov V, Molchanova L. Determination of the blood serum antioxidative activity [abstract in English]. Lab Delo 1980;7:419-20.

12 Wayner D, Burton $\mathrm{G}$, Ingold $\mathrm{K}$. The antioxidant efficiency of vitamin $\mathrm{C}$ is concentration-dependent. Biochim Biophys Acta 1986;884:119-23.

13 Whitehead TP, Thorpe GHG, Maxwell SRJ. Enhanced chemiluminiscence assay for antioxidant capacity in chemiluminiscence assay for antioxidant capaci
biological fluids. Anal Chim Acta 1992;266:265-77.

14 Gutteridge JMC, Maidt L, Poyer L. Superoxide dismutase and Fenton chemistry. Biochem f 1990;269:169-74.

15 Winterbourn CC. Comparison of superoxide with other reducing agents in biological production of hydroxyl radicals. Biochem $\mathcal{F}$ 1979;182:625-8.

16 Yamazaki I, Piette LH. ESR Spin-trapping studies on the reaction of $\mathrm{Fe}^{++}$ions with $\mathrm{H}_{2} \mathrm{O}_{2}$-reactive species in oxygen toxicity in biology. F Biol Chem 1990;265:13589-94.

17 Bland JM, Altman DG. Statistical methods for assessing agreement between two methods of clinical measurement. Lancet 1986;i:307-10.

18 Wayner DDM, Burton GW, Ingold KU, et al. The relative contributions of vitamin E, urate, ascorbate and proteins to the total peroxyl radical-trapping antioxidant activity of human blood plasma. Biochim Biophys Acta 1987;924:40819.

19 Woodford FP, Whitehead TP. Is measuring serum antioxidant capacity clinically useful? Ann Clin Biochem 1998;35: $48-56$.

20 Ames B, Cathcart R, Schiwiers E, et al. Uric acid provides an antioxidant defense in humans against oxidant and radical-caused aging and cancer. A hypothesis. Proc Nat Acad Sci U S A 1981;78:6858-62.

21 Davies K, Sevanian A, Maukkassah-Kelly S, et al. Uric acidiron ions complexes. Biochem f 1986;235:747-54

22 Valkonen M, Kuusi T. Spectrophotometric assay for total peroxyl radical-trapping antioxidant potential in human peroxyl radical-trapping antioxidan

23 Rumley AG, Paterson JR. Analytical aspects of antioxidants and free radical activity in clinical biochemistry. Ann Clin Biochem 1998;35:181-200

24 Landray MJ, Nuttall SL, Maxwell SRJ, et al. Total antioxidant capacity by enhanced chemiluminescence: contribution of urate. Ann Clin Biochem 1998;35:553-4.

25 Goode HF, Richardson N, Myers DS, et al. The effect of anticoagulant choice on apparent total antioxidant capacity using three different methods. Ann Clin Biochem 1995;32: 413-16.

26 Miller NJ. Anticoagulants for total antioxidant activity asssay. Ann Clin Biochem 1996;33:92-3.

27 Doherty G, Young I. Effect of anticoagulant choice on apparent antioxidant capacity. Ann Clin Biochem 1996;33: 93-4.

28 Rea CA, Maxwell SRJ, Maslin DJ, et al. Anticoagulant effects of antioxidant capacity. Ann Clin Biochem 1996;33: 174.

29 Miller N, Johnston J, Collis C, et al. Serum total antioxidant activity after myocardial infarction. Ann Clin Biochem 1997;34:85-90.

30 Halliwell B. Commentary. Albumin — an important extracelular antioxidant? Biochem Pharmacol 1988;37:569-71. 